\title{
Supplementation with humic substances affects the innate immunity in layer hens in posfasting phase
}

\section{El suplemento de sustancias húmicas afecta la inmunidad innata en gallinas ponedoras en fase posmuda}

\author{
Rosa Sanmiguel P, ${ }^{1 *}$ M.Sc, Iang Rondón $\mathrm{B}^{2}$ M.Sc.
}

\begin{abstract}
1 Universidad Cooperativa de Colombia, Faculty of Veterinary and Zootechnical Sciences, Laboratory of Morphophysiology, IMPRONTA Research Group. Calle 14 número 107-59, barrio El Salado, Ibagué, Colombia. 2Universidad del Tolima, Faculty of Veterinary and Zootechnical Sciences, Veterinary Diagnostics Laboratory, Inmuno-biology and Pathogenesis Research Group - GIP. Bloque 33 L105, barrio Santa Helena, Ibagué, Colombia. *Correspondence: rosa.sanmiguel@campusucc.edu.co
\end{abstract}

Received: July 2014; Accepted: February 2015.

\begin{abstract}
Objective. Asses the effect of supplementation with Humic substances (HS) over some innate immunity parameters (serum bactericidal activity, phagocytosis, bacterial agglutination, respiratory burst and lisozyme activity) in phase after fasting of layer hens. Materials and methods. 120 posfasting phase Hy Line Brown layer hens were taken which were distributed into four groups: The first and the second were supplemented with 0.1 and $0.2 \%$ of HS, respectively. The third group was supplemented with $0.25 \mathrm{mg} / \mathrm{kg}$ on levamisole hydrochloride and fourth group have no supplementation; during sixty days period. Blood samples were collected on 8th, 30th and 60th of experiment day. Results. The phagocytic index and respiratory burst increased significantly at day 30th in HS supplemented groups. Alike, serum bactericidal activity and lisozyme activity improved on 8 th day, nevertheless, changes were no evident latter. The bacterial agglutination was high in supplemented groups evaluated at everyone times. Conclusions. Results showed that HS behave as immunostimulant in the early phase after fasting layer hens.
\end{abstract}

Key words: Agglutination, bactericide activity, Lisozyme, phagocytosis (Source: DeCS).

\section{RESUMEN}

Objetivo. Evaluar el efecto de las sustancias húmicas (SH) sobre algunos parámetros de la inmunidad innata (actividad bactericida del suero, fagocitosis, aglutinación bacteriana, explosión respiratoria y actividad de la lisozima) en la fase posmuda de gallinas ponedoras. Materiales y métodos. Se utilizaron 120 gallinas ponedoras Hy Line Brown en la fase de posmuda, las cuales fueron divididas en cuatro grupos: Los dos primeros fueron suplementados con 0.1 y $0.2 \%$ de SH respectivamente, el tercer grupo fue suplementado con $0.25 \mathrm{mg} / \mathrm{kg}$ de Clorhidrato de levamisol y el cuarto grupo control sin suplemento; durante un período de 60 días. Las muestras sanguíneas se tomaron los días 8,30 y 60 del experimento. Resultados. El Índice fagocítico y la explosión respiratoria se incrementaron significativamente a partir del día 30 de suplementación con SH. De la misma manera, la actividad bactericida del suero y la actividad de la lisozima aumentaron al día 8; no obstante no se evidenciaron cambios posteriores. La aglutinación bacteriana fue significativamente mayor en los grupos suplementados en todos los tiempos evaluados. Conclusiones. Los resultados demuestran que las $\mathrm{SH}$ se comportan como agentes inmunoestimulantes en la fase temprana de la posmuda en gallinas ponedoras Hy Line Brown.

Palabras clave: Actividad bactericida, aglutinación, fagocitosis, lisozima (Fuente: DeCS). 


\section{INTRODUCTION}

During an infection the immune response, whether innate or adaptive, requires an expenditure of energy that can interfere with the production capacity of susceptible animals. Traditionally, handling infectious problems also includes reducing risk factors associated with infection, and pharmacological treatment has mainly been through the use of antibiotics, with the subsequent development of resistance that has been reported (1) coupled with a limited number of new molecules. Additionally, it has been shown that the use of antibiotics can have deleterious effects on the immune response (2). For this reason, we have opted for strategies that increase the immune response of animals against infectious challenges in the environment rather than directly attacking the agent. Thus, there has been a growing use of immunostimulant or immunomodulatory substances that have had a positive impact on the immunological parameters, minimizing the negative effects from an economic, productive and environmental standpoint (3).

In birds, several studies report the use of immunostimulatory substances, including levamisole, probiotics, prebiotics, bursa of Fabricius and thymus extract, vaccine products (3-5).

Humic substances (SH) are the end product of the biotransformation of organic matter, among which the most common are humic and fulvic acids and melanin (6). Although these substances are not reported in the tables of additives in animal diets, some studies show that they have an important potential to promote growth in broilers and laying hens (7). This could improve productive performance, carcass traits and egg quality. This can even be observed in the final stage of the production cycle, when physiologically a decrease in production and product quality occurs, effects that are diminished when the diet is supplemented with $\mathrm{SH}(8,9)$.

In the poultry industry there are different methods to extend the productive life of laying hens; a common one is inducing molt (10). The most common methods is the conventional molt program through prolonged fasting with weight loss that leads to a goal weight obtained at 18 weeks. After a complete cessation of egg production for at least 2 weeks, an improved production is achieved, since the laying is improved, as well as egg and shell quality (11). However, these conditions significantly reduce fertility and hatchability in breeding hens (12).

\section{INTRODUCCIÓN}

Los mecanismos de la respuesta inmune, innata o adaptativa durante una infección demandan un gasto energético que puede interferir con la capacidad productiva de animales susceptibles. Tradicionalmente, el abordaje de los problemas infecciosos incluye, además, de la disminución de los factores de riesgo asociados a la infección, la terapéutica farmacológica principalmente mediante el uso de antibióticos, frente a lo cual ha sido reportado el desarrollo de resistencia (1) aunado a un limitado número de nuevas moléculas. Adicionalmente, se ha demostrado que el uso de antibióticos puede tener efectos deletéreos sobre la respuesta inmune (2). Por esta razón, se ha optado por estrategias que incrementen la capacidad de respuesta inmune de los animales frente a un desafío infeccioso en el medio, más que atacar directamente al agente. Así, ha venido en crecimiento el uso de sustancias inmunoestimulantes o inmunomoduladoras, las cuales impactan positivamente los parámetros inmunológicos; minimizando los efectos negativos desde el punto de vista económico, productivo y medioambiental (3).

En aves, existen diversos trabajos que reportan el uso de inmunoestimulantes e incluyen levamisol, probióticos, prebióticos, extracto de bursa de fabricio y timo, productos vacunales (3-5)

Las sustancias húmicas $(\mathrm{SH})$ son el producto final de la biotransformación de la materia orgánica, entre las cuales las más comunes son los ácidos húmicos, fúlvicos y húmicomelánicos (6). Aunque estas sustancias no se reportan en las tablas de aditivos para el diseño de dietas animales, algunos estudios demuestran que éstas tienen un potencial importante como promotores de crecimiento en pollos de engorde y en gallinas ponedoras (7). Este hecho podría mejorar el desempeño productivo, las características de la carcasa y de la calidad de los huevos. Lo anterior puede ser observado, incluso, en la etapa final del ciclo productivo donde fisiológicamente se genera una disminución en la producción y en la calidad del producto, efectos que se menguan suplementando la dieta con $\mathrm{SH}(8,9)$.

En la industria avícola existen diferentes métodos para extender la vida productiva de las gallinas ponedoras, siendo común la inducción de la muda (10). El más común de estos métodos es el programa de muda convencional mediante ayuno prolongado con pérdida de peso que las lleve al peso obtenido a las 18 semanas de vida. Después de un cese total de la producción de huevos durante al menos 2 semanas se logra una mejor producción, ya que se mejora el porcentaje de postura, la calidad del huevo y de la cáscara (11). No obstante, bajo estas condiciones disminuye 
It has been reported that the stressful nature of molting adversely affects immune response and, in contrast, that the immune response adversely affects molting (13). In this regard, to the extent that stress generated by molting increases adrenal corticosteroids plasma levels, the immune system decreases its effectiveness by reducing the total leukocyte count and the different cellular and antibody responses $(13,14)$.

It is also noteworthy that growth performance depends on factors such as nutritional status, health status and immune performance. However, despite the existence of reports on the effects of $\mathrm{SH}$ on some production parameters, its effect on the immune response in different phases of production is unknown. This study evaluated the effect of dietary supplementation with 0.1 and $0.2 \%$ humic acids on some parameters of innate immunity (serum bactericidal activity, phagocytic index, bacterial agglutination, respiratory burst, lysozyme activity) in commercial laying hens in the post-molt phase.

\section{MATERIALS AND METHODS}

Experimental conditions. This study was conducted in installations for laying hens on the experimental farm of the Universidad Cooperativa de Colombia in El Salado, Ibague, Colombia, $03^{\circ} 24^{\prime \prime} \mathrm{N} 74^{\circ} 56^{\prime \prime}$. The average temperature in the study area was $28.2^{\circ} \mathrm{C}$.

Ethical aspects. The experiment was carried out under regulations for animal production and welfare endorsed by the Committee on Bioethics of the Universidad de Tolima under the central investigation committee. To conduct this study, the corresponding authorization from the Ethics Committee for Research of the Universidad de Tolima was requested, and a minimum statistical sample of birds (120) was used with 95\% confidence, and breeding and sample taking was performed by expert staff to minimize the stress caused by the experiment.

Experimental animals. According to the formula of finite populations, 120 clinically healthy Hy Line Brown laying hens in post-molt phase were used, which had been previously vaccinated against Gumboro (Lukert strain), Infectious Viral Bronchitis (Massachusetts strain) and New Castle (B1 strain) from the Laverlam laboratory. The hens were kept on a raised floor, were moved to cage at 16 weeks and underwent traditional molt with prolonged fasting for 12 days and received $5 \mathrm{~g}$ of calcium carbonate supplements per bird during fasting. significativamente la fertilidad y la eclosionabilidad en gallinas reproductoras (12).

Se ha reportado que la naturaleza estresante de la muda afecta negativamente la respuesta inmune y, en contraposición, la respuesta inmune afecta negativamente la muda (13). En este sentido, en la medida que el estrés generado por la muda incrementa los niveles de corticoides adrenales plasmáticos, el sistema inmune disminuye su efectividad reduciendo el conteo total de leucocitos y sus diferentes respuestas humorales y celulares $(13,14)$.

También es de resaltar que los parámetros productivos de las aves dependen de factores tales como el estado nutricional, estado sanitario y el desempeño inmunológico. No obstante, a pesar de existir reportes acerca del efecto de las SH sobre algunos parámetros productivos, se desconoce su efecto sobre la respuesta inmune en las diferentes fases de producción. La presente investigación evaluó el efecto de la suplementación de la dieta con 0.1 y $0.2 \%$ de ácidos húmicos sobre algunos parámetros de la inmunidad innata (actividad bactericida del suero, índice fagocítico, aglutinación bacteriana, explosión respiratoria, actividad de la lisozima) en gallinas ponedoras comerciales en la fase de posmuda.

\section{MATERIALES Y MÉTODOS}

Condiciones experimentales. Este estudio fue realizado en las instalaciones de gallinas ponedoras enjauladas de la granja experimental de la Universidad Cooperativa de Colombia, sede El Salado, Ibagué, Colombia, $03^{\circ} 24^{\prime \prime} \mathrm{N} 74^{\circ} 56^{\prime \prime}$. La temperatura promedio del área de estudio fue de $28.2^{\circ} \mathrm{C}$.

Aspectos éticos. El experimento fue realizado bajo la normatividad tanto en producción animal como en bienestar de los mismos, avalado por el comité de Bioética de la Universidad del Tolima adscrito al comité central de investigaciones. Para el desarrollo de este proyecto se solicitó la autorización correspondiente al Comité de ética de Investigaciones de la Universidad del Tolima, en la cual se sustentó una mínima muestra estadística necesaria de aves (120 aves) con 95\% de confianza y se realizó un procedimiento de cría y toma de muestras refinado con personal experto que minimice el estrés ocasionado por el experimento.

Animales experimentales. De acuerdo con la fórmula de poblaciones finitas se tomaron 120 gallinas ponedoras Hy line brown en fase de producción posmuda, clínicamente sanas, las cuales se vacunaron previamente contra Gumboro (cepa Lukert), Bronquitis Viral infecciosa (cepa Massachussetts) y New Castle (cepa B1) del laboratorio Laverlam. Las gallinas se mantuvieron levantadas en piso, trasladadas a Jaula 
Humic substances. Humic substances subjected to the experiment were obtained from the biotransformation of cachaza, a product of sugarcane and alcohol. This underwent a biotechnological process to transform and stabilize organic matter ( $80 \%$ of humic acids) to obtain a pH of 6.4 , density of $0.73 \mathrm{~g} / \mathrm{cm}^{3}$, maximum humidity of $12.32 \%$, and $62.45 \%$ ash. This product was supplied by PBA Biotechnology Products.

Experimental design. A completely randomized design was used where 120 chickens were divided into four groups for eight weeks in the post-molting phase. Two treatments were supplemented with humic substances ( 0.1 to $0.2 \%$ ), and a positive control group was supplemented with levamisole (levamisole hydrochloride 4\%) administered in drinking water at a concentration of $0.25 \mathrm{mg} / \mathrm{kg}$ day, as well as a negative control group without diet supplements. In each treatment there were 10 experimental units (EU), each comprising 3 hens placed in individual cages of $20 \mathrm{~cm} \times 40 \mathrm{~cm} \times 30$ $\mathrm{cm}$ in a three level pyramidal module. In all cases the water was supplied automatically ad libitum.

Day zero for the experiment was the first postmolt day, once production dropped to $0 \%$ feed consumption was started. Blood samples for the corresponding hematologic and innate immunity tests were taken on day 8,30 and 60 of the experiment.

Sample collection. Hens were immobilized by trained staff to obtain blood samples by puncturing the metatarsal vein after disinfecting the area with $70 \%$ ethyl alcohol. Disposable syringes, $1 \mathrm{ml} 27 \mathrm{G} \times 1 / 2$, were used. The collection was made in microtubes $1.5 \mathrm{ml}$ with EDTA and dry microtubes $(0.3$ and $0.7 \mathrm{ml}$ of blood respectively). The phagocytic index and respiratory burst response of white blood cells was evaluated in the blood collected in microtubes with EDTA. The blood collected in microtubes was dry centrifuged at $5000 \mathrm{~g}$ for 5 minutes, the serum was grouped according to each experimental unit to evaluate bactericidal activity, lysozyme, and bacterial agglutination.

Phagocytic activity test. Whole blood was kept at room temperature and diluted 1:20 in a Hanks Balanced Salt Solution (reference 14175079; Gibco/Invitrogen) with $1 \% \mathrm{NaCl}$. Then $60 \mathrm{ul}$ of the dilution was placed in a chamber slide (LabTekII Chamber Slide, 8 wells) along with 250 ul of a $E$. coli suspension of avian origin to an optical density of 0.80 ( 1 x 108 CFU). The micro preparation was done in duplicate and incubated for 15 minutes at $40.5^{\circ} \mathbf{C}$. The phagocytic a las 16 semanas y sometidas a régimen de muda tradicional con ayuno prolongado durante 12 días y suplementadas con $5 \mathrm{~g}$ de carbonato de calcio por ave durante el ayuno.

Sustancias húmicas. Las sustancias húmicas sometidas al experimento se obtuvieron de la biotransformación de la cachaza, hoja y vinaza de la producción de azúcar y alcohol. Estos insumos se sometieron a un proceso biotecnológico de transformación y estabilización de la materia orgánica (80\% de ácidos húmicos), obteniendo un $\mathrm{pH}$ de 6.4, densidad de $0.73 \mathrm{~g} / \mathrm{cm}^{3}$, humedad máxima de $12.32 \%$ y $62.45 \%$ de cenizas. Este producto fue suministrado por el ingenio PBA Productos Biotecnológicos.

Diseño experimental. Fue realizado un diseño completamente al azar donde 120 gallinas se distribuyeron en cuatro grupos durante ocho semanas en la fase posmuda. Dos tratamientos suplementados con sustancias húmicas ( 0.1 y $0.2 \%)$, un grupo control positivo suplementado con levamisol (Clorhidrato de levamisol al 4\%) en el agua de bebida a una concentración de $0.25 \mathrm{mg} / \mathrm{kg}$ día y un grupo control negativo sin suplementación en la dieta. En cada tratamiento hubo 10 unidades experimentales (UE) conformadas cada una por 3 gallinas ubicadas en jaulas individuales de $20 \mathrm{~cm} \times 40 \mathrm{~cm} \times 30 \mathrm{~cm}$, en módulo piramidal de tres niveles. En todos los casos el agua se suministró ad libitum con bebedero automático.

El día cero para el experimento fue el primer día posmuda en el cual se inició el consumo de alimento una vez la producción bajó al 0\%. Las muestras sanguíneas para realizar las correspondientes pruebas hematológicas y de inmunidad innata se tomaron en el día 8, 30 y 60 del experimento.

Colecta de muestras. Las gallinas fueron inmovilizadas por personal capacitado para obtener las muestras sanguíneas mediante punción en la vena metatarsiana, previa desinfección del área con alcohol etílico al $70 \%$. Para ello, se utilizaron jeringas estériles desechables de $1 \mathrm{ml}, 27 \mathrm{G} \times 1 / 2$. La colecta se realizó en microtubos de $1.5 \mathrm{ml}$ con EDTA y microtubos secos ( 0.3 y $0.7 \mathrm{ml}$ de sangre respectivamente). De la sangre colectada en los microtubos con EDTA se evaluó la respuesta del índice fagocítico y de la explosión respiratoria de las células sanguíneas blancas. La sangre colectada en los microtubos secos se centrifugó a $5000 \mathrm{~g}$ durante 5 minutos, se extrajo el suero sanguíneo agrupándose según cada unidad experimental para evaluar la actividad bactericida, de la lisozima y la aglutinación bacteriana.

Prueba de actividad fagocitaria. La sangre entera fue mantenida a temperatura ambiente y diluida 1:20 en Solución Salina balanceada de Hanks (referencia 14175079; Gibco/Invitrogen) 
process was stopped by cooling on iced sheets as described by Millet et al (15). It was washed with Hanks saline solution in each chamber and then they were fixed with $300 \mu$ l of methanol (99.9\% pure) on ice for 5 min, stained with Hemacolor and at least 100 cells per chamber were counted as suggested by Millet et al (15). The results were interpreted as a phagocytic index (IF): Percentage of heterophiles containing bacteria $X$ the average number of bacteria that have been ingested by heterophiles (16).

Respiratory burst test. It was performed following the spectrophotometric method described by Mohanty \& Sahoo (17). Briefly, $50 \mu \mathrm{l}$ of blood was placed in a vial with $50 \mu \mathrm{l}$ of nitro blue tetrazolium (NBT tablet) $0.2 \%$ and incubated for 30 minutes at $25^{\circ} \mathrm{C}$. Then $1 \mathrm{ml}$ of NN-dimethylformamide was added at $99.8 \%$ (reference 161785) to solubilize the reduced formazan and this mixture was centrifuged at $2000 \times \mathrm{g}$ for 5 minutes. Then $200 \mu \mathrm{l}$ of the supernatant was taken in duplicate and plated in a $U$ bottom multiwell plate to read the optical density in an ELISA plate reader at $650 \mathrm{~nm}$. $200 \mu \mathrm{l}$ of $\mathrm{NN}$-dimethyl formamide was used as a target.

Lysozyme activity test. For this test, a bacterial suspension of Micrococcus luteus (lisodeikticus) ATCC 4698 (Reference M3770; Sigma Aldrich, Germany) was prepared to an optical density of 0.60 $\left(1 \times 10^{8} \mathrm{CFU}\right)$. In a multiwell plate with 96 wells 20 $\mu$ of serum from the pool of each experimental unit was placed and $180 \mu \mathrm{l}$ of suspension was added. Reading was performed using a spectrophotometer with a $650 \mathrm{~nm}$ filter and was repeated after 10 minutes of incubation at room temperature (15).

Bacterial agglutination test. A $1: 2$ serial dilution was performed with $25 \mu$ l of serum to equal volumes of PBS and $25 \mu$ l of $E$. coli solution (108 cells $/ \mathrm{ml}$ ) that was previously inactivated with formalin in a multiwell $U$ bottom plate. The plates were incubated during the night at room temperature and titers were calculated as the reciprocal of the serum dilution that had the highest complete agglutination of the bacterial cells (18).

Serum bactericidal activity test. This test was performed using the technique described by Low and Sin (19). Briefly, blood was collected without anticoagulant and kept at room temperature for one hour. Subsequently, it was centrifuged at $2500 \mathrm{~g}$ for 5 minutes and the supernatant serum was removed. A bacterial suspension in PBS was prepared from $E$. coli of avian origin to an optical density of 0.80 , which was diluted $1: 10$ 3 times serially. con $1 \%$ de $\mathrm{NaCl}$. Luego, $60 \mu \mathrm{l}$ de la dilución fueron depositados en un portaobjetos con cámara (Lab-TekII Chamber Slide, 8 wells), adicionándose $250 \mu$ de una suspensión de $E$. coli de origen aviar a una densidad óptica de 0.80 ( $1 \times 10^{8}$ UFC). El micropreparado se hizo por duplicado y fue incubado durante 15 minutos a $40.5^{\circ} \mathrm{C}$. El proceso de fagocitosis fue detenido mediante enfriamiento de las láminas sobre hielo según lo descrito por Millet et al (15). Se realizó un lavado con Solución Salina balanceada de Hanks en cada cámara, luego fueron fijadas con $300 \mu$ de Metanol (99.9\% de pureza) sobre hielo durante 5 minutos, se realizó tinción con Hemacolor y se contaron al menos 100 células por cámara, según lo sugerido por Millet et al (15). Los resultados se interpretaron como el índice fagocítico (IF): Porcentaje de heterófilos que contiene bacterias $X$ el número promedio de bacterias que han sido ingeridas por los heterófilos (16).

Prueba de explosión respiratoria. Se realizó siguiendo la técnica espectrofotométrica descrita por Mohanty \& Sahoo (17). Brevemente, se dispusieron de $50 \mu$ l de sangre en un vial con $50 \mu$ de Nitroblue tetrazolium (NBT Tablet) $0.2 \%$ y se incubó durante 30 minutos a $25^{\circ} \mathrm{C}$. Luego se adicionó $1 \mathrm{ml}$ de NNdimetil formamida al 99.8\% (referencia 161785) para solubilizar el formazán reducido y esta mezcla se centrifugó a 2000 x g durante 5 minutos. Se tomaron $200 \mu \mathrm{l}$ del sobrenadante por duplicado y se depositó en una placa multipozos de fondo en U para la lectura de la densidad óptica mediante lector de placas de ELISA a $650 \mathrm{~nm}$. Como blanco se utilizaron $200 \mu \mathrm{lde}$ NN-dimetil formamida.

Prueba de actividad de la lisozima. Para esta prueba, se preparó una suspensión bacteriana de Micrococcus luteus (lisodeikticus) ATCC 4698 (referencia M3770; Sigma Aldrich, Alemania) a una densidad óptica de 0.60 ( 1 X $10^{8}$ UFC). En una placa multipozos de 96 pozos se colocaron $20 \mu \mathrm{L}$ de suero sanguíneo provenientes del pool de cada unidad experimental y se adicionaron $180 \mu$ lde la suspensión. Se realizó la lectura en un espectrofotómetro con filtro de 650 nm y se repitió a los 10 minutos de incubación a temperatura ambiente (15).

Prueba de aglutinación bacteriana. Se realizó un serial de dilución $1: 2$ con $25 \mu$ de suero sanguíneo a igual volumen de PBS y se adicionó $25 \mu$ l de solución de $E$. coli ( $10^{8}$ células/ $\mathrm{ml}$ ) previamente inactivada con formalina en placa multipozos de fondo en $U$. Las placas se incubaron en el transcurso de la noche a temperatura ambiente y los títulos se calcularon como el recíproco de la dilución de suero que presentó la más alta aglutinación completa de las células bacterianas (18). 
$2 \mu \mathrm{l}$ of the diluted suspension of the bacteria was incubated with $20 \mu$ l of the serum in a vial for 1 hour at $37^{\circ} \mathrm{C}$. PBS was used for the control group to replace blood serum. It was massively planted in Trypticase Soy Agar (TSA) and incubated at $37^{\circ} \mathrm{C}$ for 24 hours, after which UFC counting was done.

Statistical analysis. The response variables were analyzed depending on the fulfillment of statistical assumptions and subjected to ANOVA variance analysis followed by a post hoc Tukey test. Nonparametric data were analyzed using Kruskal-Wallis statistics and Dunn's multiple comparison test. These analysis were performed using Graphpad Prism software version 5.03 (GraphPad software) establishing a $p<0.05$ value below which the variable values in each treatment were considered significantly different.

\section{RESULTS}

Parameters of innate immunity. On the eighth day of the experiment, hens supplemented with $0.1 \%$ presented better IF than other groups (Figure 1). By day 30, supplementation with $\mathrm{SH}$ at 0.1 and $0.2 \%$ resulted in a statistically higher IF $(p<0.05)$ than the non-supplemented groups. At day 30, the IF of the supplemented $\mathrm{SH}$ groups decreased ( 36.8 and 36.9 ) but compared to non-supplemented groups SH (3.9 and 24.5) which showed a statistically higher IF $(p<0.05)$. In treatment 1 it was visibly noticed that the IF decreased over time, and the eighth day of supplementation showed the highest IF (71.75) while on days 30 and 60 it decreased to 36.8 and 36.1 respectively (Table 1 ).

Birds supplemented with $0.1 \% \mathrm{SH}$ have lower respiratory burst values $(p<0.05)$ than the group
Prueba de actividad bactericida del suero. Esta prueba fue realizada mediante la técnica descrita por Low y Sin (19). Brevemente, se colectó la sangre sin anticoagulante, mantenida a temperatura ambiente durante una hora. Posteriormente, se centrifugó a $2500 \mathrm{~g}$ por 5 minutos y se extrajo el suero sobrenadante. Se preparó una suspensión bacteriana en PBS de $E$. coli de origen aviar a una densidad óptica de 0.80 , el cual fue diluido $1: 10$, en 3 ocasiones de forma seriada.

Se incubaron $2 \mu \mathrm{l}$ del diluido de la suspensión de la bacteria con $20 \mu \mathrm{l}$ del suero en un vial por 1 hora a $37^{\circ} \mathrm{C}$. Para el grupo control se usó PBS en remplazo de suero sanguíneo. Se sembró masivamente en Agar Tripticasa Soya (TSA), y se incubó a $37^{\circ} \mathrm{C}$ durante 24 horas, posterior a lo cual se llevó a cabo el conteo de UFC.

Análisis estadístico. Las variables de respuestas fueron analizadas dependiendo del cumplimiento de los supuestos estadísticos y sometidas a un análisis de varianza ANOVA seguido por el test pos hoc de Tukey. Los datos no paramétricos se analizaron mediante el estadístico KruskalWallis y la prueba de comparación múltiple de Dunn. Estos análisis fueron realizados mediante software Graphpad Prism, version 5,03 (GraphPad Sofwtare) estableciendo un valor $\mathrm{p}<0.05$ por debajo del cual se consideraron significativamente diferentes los valores de las variables en cada tratamiento.

\section{RESULTADOS}

Parámetros de inmunidad innata. En el octavo día del experimento, las gallinas suplementadas con $0.1 \%$ presentaron mejor IF que los demás grupos (Figura 1). En el día 30, la suplementación con $\mathrm{SH}$ al 0.1 y $0.2 \%$ generó un IF estadísticamente
A

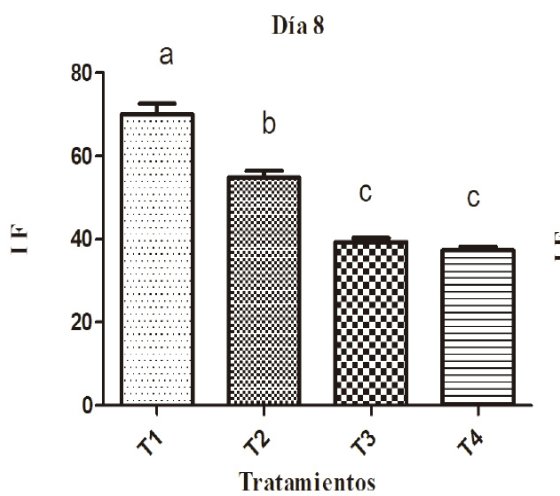

B

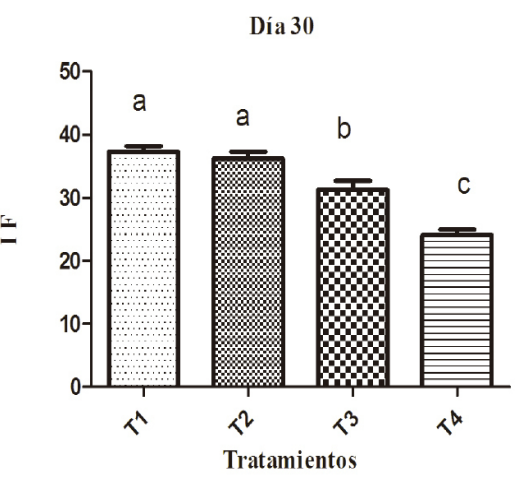

C

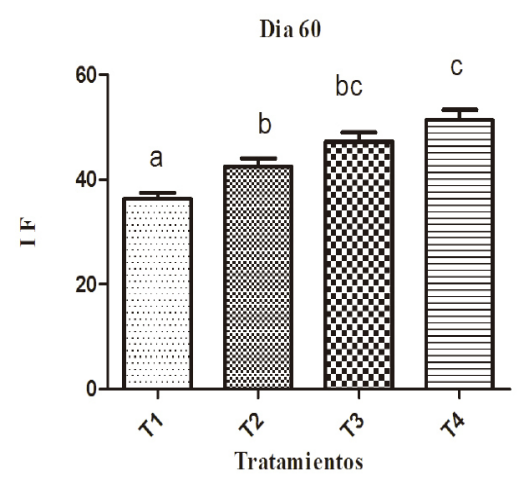

Figure 1. Effect of SH supplements (\%) on the phagocytic index (IF) in different treatments (T1, T2, T3 and T4). T1: $0.1 \%, T 2: 0.2 \%, T 3: 0.25 \mathrm{mg} / \mathrm{kg}$ of levamisole, T4: without supplement, day $8(\mathrm{~A}), 30(\mathrm{~B})$ and 60 (C). Different letters indicate statistical differences $(p<0.05)$. 
supplemented with Levamisole on the eighth day and the negative control group on day 30 of the experiment (Figure 2). The groups supplemented with $0.2 \% \mathrm{SH}$ had higher respiratory burst values than the unsupplemented groups and on day 60 there were no significant differences $(p<0.05)$ (Table 1).

Supplementation with $0.1 \% \mathrm{SH}$ resulted in a significantly greater ABS than the group mayor $(p<0.05)$ que los grupos no suplementados. Al día 30, el IF de los grupos suplementados con SH disminuyó (36.8 y 36.9) pero en comparación con los grupos no suplementados con SH (3.9 y 24.5) los cuales presentaron un IF estadísticamente mayor $(p<0.05)$. En el tratamiento 1 se notó visiblemente que el IF disminuyó con el tiempo, así el octavo día de suplementación presentó el mayor IF (71.75) mientras que el día 30 y 60 disminuyó a 36.8 y 36.1 respectivamente (Tabla 1 ).

Table 1. Phagocytic index, respiratory burst, serum bacteria activity bacterial agglutination in hens with $\mathrm{SH}$ supplements.

\begin{tabular}{|c|c|c|c|c|c|c|c|c|c|}
\hline \multirow[t]{2}{*}{ Variables } & \multicolumn{8}{|c|}{ Treatments } & \multirow{3}{*}{$\begin{array}{c}\text { K. W } \\
\text { P value } \\
\end{array}$} \\
\hline & \multicolumn{2}{|r|}{ T1 } & \multicolumn{2}{|r|}{ T2 } & \multicolumn{2}{|r|}{ T3 } & \multicolumn{2}{|r|}{ T4 } & \\
\hline \multicolumn{9}{|l|}{ Phagocytic index } & \\
\hline Day 8 & $71.75^{a}$ & $(60-80)$ & $55.5^{b}$ & $(49-61)$ & $38.8^{c}$ & $(35-43)$ & $38.7^{c}$ & $(33-41)$ & $0.0001 * * *$ \\
\hline Day 30 & $36.8^{\mathrm{a}}$ & $(34-41)$ & $36.9^{a}$ & $(33-40)$ & $31.9^{b}$ & $(26-36)$ & $24.5^{c}$ & $(21-27)$ & $0.004 * *$ \\
\hline Day 60 & $36.1^{\mathrm{a}}$ & $(30-41)$ & $43.9^{b}$ & $(37-49)$ & $46.5^{\mathrm{bc}}$ & $(40-54)$ & $51^{c}$ & $(44-58)$ & 0.1073 \\
\hline \multicolumn{10}{|c|}{ Respiratory burst } \\
\hline Day 8 & $0.14^{c}$ & $(0.11-0.16)$ & $0.16^{\mathrm{bc}}$ & $(0.12-0.17)$ & $0.18^{a}$ & $(0.16-0.19)$ & $0.16^{\mathrm{b}}$ & $(0.13-0.18)$ & $0.0001 * * *$ \\
\hline Day 30 & $0.12 \mathrm{ab}$ & $(0.10-0.14)$ & $0.14^{a}$ & $(0.12-0.15)$ & $0.12^{\mathrm{b}}$ & $(0.10-0.13)$ & $0.12^{\mathrm{b}}$ & $(0.10-0.13)$ & $0.0023 * *$ \\
\hline Day 60 & 0.14 & $(0.12-0.15)$ & 0.14 & $(0.12-0.15)$ & 0.14 & $(0.12-0.15)$ & 0.14 & $(0.12-0.15)$ & 0.9672 \\
\hline \multicolumn{10}{|c|}{ Serum bacteria activity } \\
\hline Day 8 & $115^{\mathrm{ab}}$ & $(107-119)$ & $98.5^{c}$ & $(94-105)$ & $117.5^{\mathrm{a}}$ & $(112-123)$ & $98.5^{c}$ & $(95-104)$ & $0.0001 * * *$ \\
\hline Day 30 & $117^{a}$ & $(106-121)$ & $110^{\mathrm{ab}}$ & $(102-119)$ & $100^{\mathrm{bc}}$ & $(88-117)$ & $93^{c}$ & $(84-107)$ & $0.0002 * * *$ \\
\hline Day 60 & 99 & $(80-117)$ & 91 & $(81-111)$ & 77 & $(58-105)$ & 90 & $(79-101)$ & 0.07 \\
\hline \multicolumn{10}{|c|}{ Bacterial agglutination } \\
\hline Day 8 & $32^{\mathrm{a}}$ & $(32-64)$ & $32^{\mathrm{ab}}$ & $(32-32)$ & $16^{\mathrm{bc}}$ & $(8-32)$ & $16^{c}$ & $(8-32)$ & $0.0001 * * *$ \\
\hline Day 30 & $32^{\mathrm{a}}$ & $(32-64)$ & $48^{\mathrm{ab}}$ & $(16-64)$ & $16^{c}$ & $(8-16)$ & $16^{\mathrm{bc}}$ & $(16-16)$ & $0.0001 * * *$ \\
\hline Day 60 & $64^{a}$ & $(64-128)$ & $48^{\mathrm{ab}}$ & $(32-64)$ & $32^{\mathrm{b}}$ & $(16-32)$ & $16^{c}$ & $(16-16)$ & $0.0001 * * *$ \\
\hline
\end{tabular}

Median values and quartile ranges (in parentheses) of 120 hens. T1: SH 0.1\%, T2: 0.2SH\% T3: 0.25 mg / kg levamisole, T4: no supplement. Different letters indicate statistical differences $(p<0.05) * * p<0.01$

supplemented with $0.2 \%$ and the nonsupplemented group on the eighth day ( $p<0.05)$. By day 30 , SH supplementation had a significantly greater ABS than the unsupplemented groups $(p<0.05)$, as shown in figure 3 .

Serum bactericidal activity increased on day 30 $(p<0.05)$ and was at the same level on day 60, in which no differences between groups were observed ( $p>0.05)$; (Figure 3).

As shown in figure 4 , on day 8 bacterial agglutination was higher in the groups supplemented with $0.1 \% \mathrm{SH}$ than in the other groups $(p<0.05)$.

On days 30 and 60 it was seen that supplementation with humic substances significantly improves bacterial agglutination activity $(p<0.05)$

On day 30 of the experiment no significant difference in lysozyme activity was found between
Los animales suplementados con $0.1 \%$ de $\mathrm{SH}$ presentaron menores valores de explosión respiratoria $(p<0.05)$ que el grupo suplementado con Levamisol al día ocho, y que el grupo control negativo, en el día 30 del experimento (Figura 2). Los grupos suplementados con $0.2 \%$ de $\mathrm{SH}$ presentaron valores de explosión respiratoria mayores que los no suplementados y en el día 60 no hubo diferencias significativas $(p<0.05)$ (Tabla 1).

La suplementación con $0.1 \%$ de $\mathrm{SH}$ presentó una $A B S$ significativamente mayor que el grupo suplementado con $0.2 \%$ y que el grupo no suplementado en el día octavo $(p<0.05)$. Para el día 30, la suplementación con SH presentó una ABS significativamente mayor que los grupos no suplementados $(p<0.05)$ como se presenta en la figura 3.

La actividad bactericida del suero aumentó el día $30(\mathrm{p}<0.05)$ y permaneció al mismo nivel el día 60 , en el cual no se presentaron diferencias entre grupos ( $p>0.05)$ (Figura 3 ). 

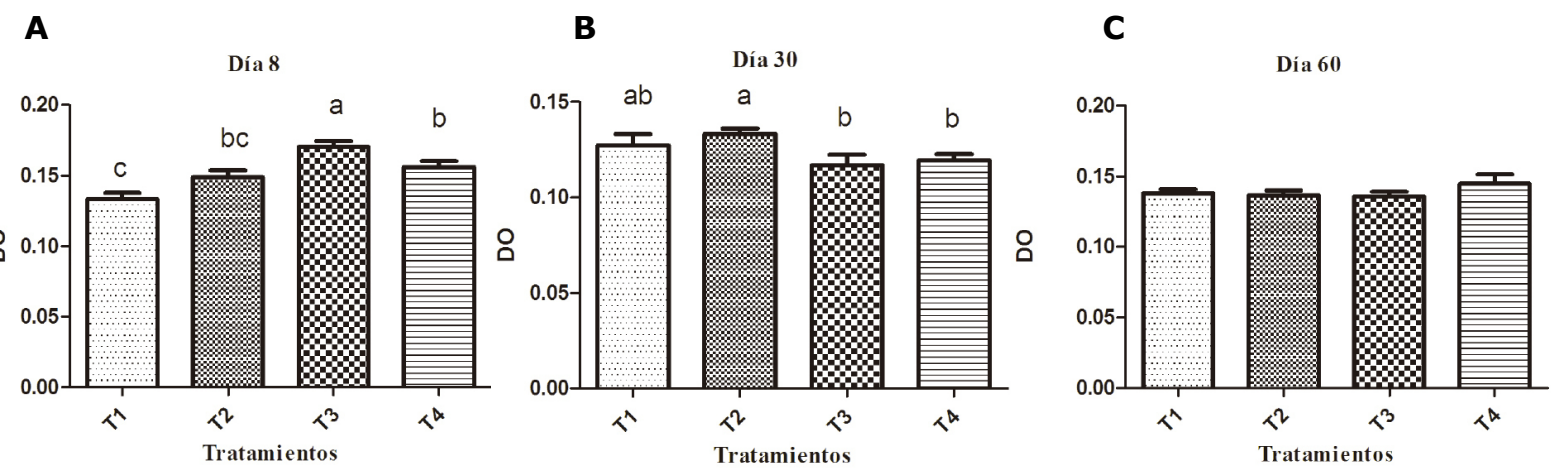

Figure 2. Effect of $\mathrm{SH}$ supplements on respiratory burst using the Kruskal Wallis test in different treatments (T1, T2, T3 y T4). T1: $0.1 \%, \mathrm{~T} 2: 0.2 \%, \mathrm{~T} 3: 0.25 \mathrm{mg} / \mathrm{kg}$ of levamisole, T4: without supplement, day 8 (A), $30(B)$ and $60(C)$. Different letters indicate statistical differences $(p<0.05)$.
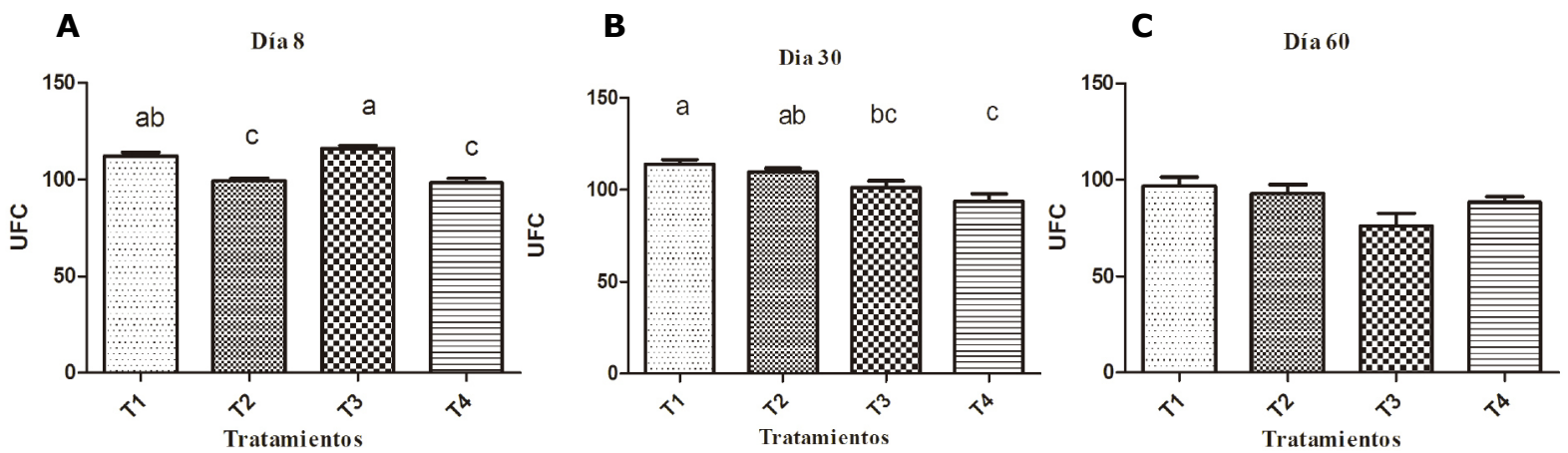

Figure 3. Effect of $\mathrm{SH}$ supplements on serum bacteria activity in different treatments (T1, T2, T3 y T4). T1: $0.1 \%, \mathrm{~T} 2: 0.2 \%, \mathrm{~T} 3: 0.25 \mathrm{mg} / \mathrm{kg}$ of levamisole, T4: without supplement, day $8(\mathrm{~A}), 30(\mathrm{~B})$ and 60 (C). Different letters indicate statistical differences $(p<0.05)$.

A

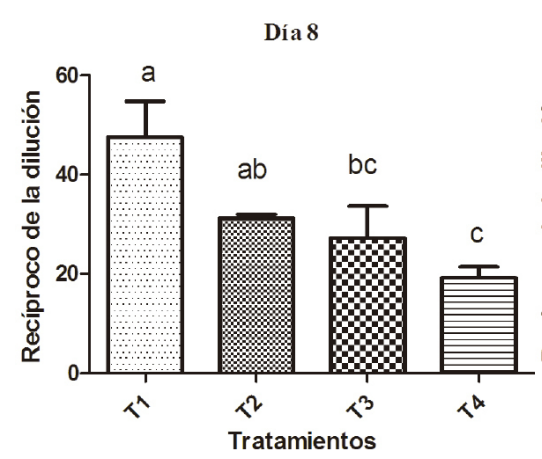

B

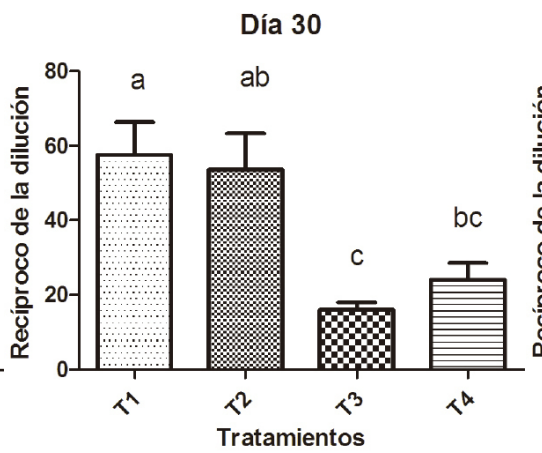

C

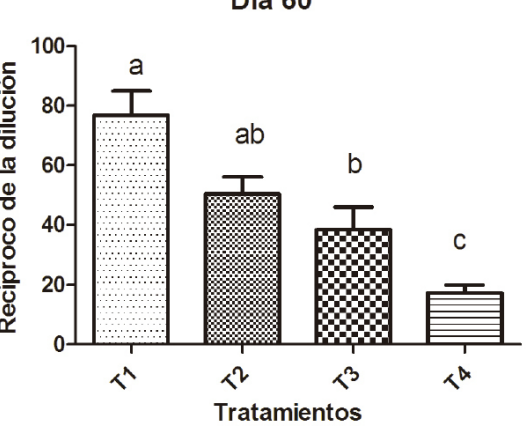

Figure 4. Effect of $\mathrm{SH}$ supplements on bacterial agglutination in different treatments (T1, T2, T3 y $\mathrm{T} 4) . \mathrm{T} 1: 0.1 \%$, T2: $0.2 \%$, T3: $0.25 \mathrm{mg} / \mathrm{kg}$ of levamisole, T4: without supplement, day 8 (A), 30 (B) and 60 (C). Different letters indicate statistical differences $(p<0.05)$.

treatments when the DO difference relative to the negative control ( $p>0.05$ ) was analyzed. On day 60 , the group of hens supplemented with $0.1 \% \mathrm{SH}$ showed a greater difference in the DO regarding the negative control in comparison with the supplemented group with $0.2 \% \mathrm{SH}(\mathrm{p}<0.05)$ (Table 2).
Como se observa en la figura 4 , el día 8 , la aglutinación bacteriana fue más alta en los grupos suplementados con $0.1 \%$ de SH que en los demás grupos $(p<0.05)$.

En los días 30 y 60 se evidenció que la suplementación con sustancias húmicas mejora significativamente la actividad de la aglutinación bacteriana $(p<0.05)$ 
Table 2. Difference in lysozyme activity compared to negative control hens supplemented with $\mathrm{SH}$.

\begin{tabular}{lcccc}
\hline & \multicolumn{3}{c}{ Treatments } & KW \\
& T1 & T2 & T3 & P value \\
\hline Day 8 & $-0.001^{\mathrm{b}}$ & $-0.002^{\mathrm{b}}$ & $0.004^{\mathrm{a}}$ & $0.01^{* *}$ \\
& $(0.001-0.002)$ & $(0.014-0.002)$ & $(0.004-0.002)$ & \\
Day 30 & 0.001 & 0.001 & 0.002 & 0.848 \\
& $(0.001-0.004)$ & $(0.002-0.002)$ & $(0.001-0.003)$ & \\
Day 60 & $0.001^{\mathrm{a}}$ & $-0.003^{\mathrm{b}}$ & $0.001^{\mathrm{a}}$ & $0,01^{* *}$ \\
& $(0.001-0.003)$ & $(0.001-0.008)$ & $(0.003-0.004)$ &
\end{tabular}

Values in the difference between median values and quartile range (in parenthesis) for the negative control group of 120 hens by Kruskal Wallis. T1: $\mathrm{SH} 0.1 \%, \mathrm{~T} 2: 0,2 \mathrm{SH} \% \mathrm{~T} 3: 0.25 \mathrm{mg} / \mathrm{kg}$ levamisole, T4: no supplement. Different letters indicate statistical differences $(p<0.05)$. ** $(p<0.01)$

\section{DISCUSSION}

Heterophils are phagocytic microbicidal cells that primarily depend on non-oxidative mechanisms for antimicrobial activity, and since they do not contain catalase or myeloperoxidase, this means the production of hydrogen peroxide is much more limited than in mammalian neutrophils (20). Additionally, it is known that macrophages are capable of trapping foreign antigens and initiating an adaptive immune response phase (21). In this study it was found that the $\mathrm{SH}$ improve IF on day 8 and 30 of the post-molting phase, but at day 60 is even lower than the unsupplemented groups, so it is understood that the increase in phagocytic activity generated by $\mathrm{SH}$ in the early post-molt stage has limited stimulatory functions and for unknown reasons the phagocytes not soon recover their natural activity quickly, and therefore day 60 is significantly different from the control group.

To the authors' knowledge there are no reports in literature on the effect $\mathrm{SH}$ has on these immune parameters. However, similar results were found using other immunostimulatory molecules. Engstad et al (22) demonstrated that human leukocytes increase their immunological activity with $\beta$-glucans; however, Chuammitri et al (23) demonstrated that the phagocytic index and bactericidal activity of heterophiles did not show significant differences between those treated with $\beta$-glucans and ascorbic acid and those that were untreated, while murine macrophage phagocytosis is increased by Panax ginseng and other immunomodulators (24).

Furthermore, reports show that phagocytic activity is influenced by genetics. Swaggerty et al (25) compared the phagocytic and bactericidal activity of chicken heterophiles in fast and slow feathering. The authors demonstrated that fastfeathering chickens showed a higher phagocytic
El día 30 del experimento, no se encontró diferencia significativa de la actividad de la lisozima entre los tratamientos cuando se analizó la diferencia de DO con respecto al control negativo $(p>0.05)$. El día 60 , el grupo de gallinas suplementadas con $0.1 \%$ de SH presentó una mayor diferencia en la DO con respecto al control negativo en comparación con el grupo suplementado con $0.2 \%$ se $\mathrm{SH}(\mathrm{p}<0.05)$ (Tabla 2).

\section{DISCUSIÓN}

Los heterófilos son células fagocíticas y microbicidas que dependen primariamente de mecanismos no oxidativos para la actividad antimicrobiana, ya que no contienen catalasa ni mieloperoxidasa, esto hace que la producción de peróxido de hidrógeno sea mucho menor que en los neutrófilos de los mamíferos (20). Adicionalmente, es conocido que los macrófagos son capaces de atrapar antígenos foráneos e iniciar la fase adaptativa de la respuesta inmune (21). En el presente estudio se encontró que las SH mejoran el IF en el día 8 y 30 de la fase posmuda, pero al día 60 es incluso menor que los grupos no suplementados, por lo cual se deduce que el aumento en la actividad fagocítica generado por las SH en la etapa temprana de la posmuda tiene un límite de funcionalidad estimulatoria y por razones desconocidas los fagocitos no recuperan pronto su natural actividad, por consiguiente al día 60 se refleja en la diferencia significativa con respecto al grupo control.

En la literatura no existen reportes, a conocimiento de los autores, del efecto de las $\mathrm{SH}$ sobre estos parámetros inmunes. No obstante, con el uso de otras moléculas inmunoestimulantes se han encontrado resultados similares. Así, Engstad et al (22) demostraron que los leucocitos de humanos incrementan su actividad inmunológica con $\beta$-glucanos, no obstante, Chuammitri et al (23) demostraron que el índice fagocítico y actividad bactericida de heterófilos no presentaron diferencias significativas entre los tratados con $\beta$-glucanos, ácido ascórbico y los no tratados mientras que en murinos la fagocitosis de macrófagos es incrementada por Panax ginseng y otros inmunomoduladores (24).

Por otro lado, reportes demuestran que la actividad fagocítica es influenciada por la genética. Swaggerty et al (25) compararon la actividad fagocítica y bactericida de heterófilos de pollos de emplume rápido y emplume lento. Los autores demostraron que los pollos de emplume rápido presentaron mayor índice fagocítico y mayor actividad bactericida. Por tal motivo se sugiere realizar estudios que permitan visualizar la diferencia del efecto de las $\mathrm{SH}$ en la respuesta inmune, de acuerdo a diferentes líneas genéticas de pollo de engorde y producción de huevo respectivamente. 
index and bactericidal activity. Therefore it is suggested study the difference $\mathrm{SH}$ has on the immune response according to the different genetic lines existing in broiler and egg production, respectively.

Results found in this work on bacterial agglutination infer that supplementation with $\mathrm{SH}$ at 0.1 and $0.2 \%$ improves the effects of bacterial agglutination serum in laying hens ( $p$ $<0.05$ ). Although no published data were found on this species to compare, these results relate to what was presented by Behera et al (18), who conducted a parenteral immunization with glycolic acid on Rohita labeo and reported that the treated group showed a significantly higher difference in bacterial agglutination test on the first day of immunization without obtaining significant differences at days 21 and 42, data that differ from the results presented in this work since $\mathrm{SH}$ supplementation significantly improved bacterial agglutination in all sampling $(8,3060)$.

Lysozyme activity showed significant improvement on day 60 with a supplementation of $0.1 \% \mathrm{SH}$. According to Li et al (26), the egg is nature's richest source of lysozyme. Hence it is relevant to consider whether the increase in thickness of egg albumin is related to an increase in the proportion of Lysozyme, which is in turn transferred at the egg level to breeding hens.

The blood serum of chickens supplemented with $\mathrm{SH}$ had a higher bacterial agglutination during the entire experiment, even surpassing the positive control group; however, publications on this subject that consider previous results have not been found.

Respiratory burst tests showed that at day 30 of the post-molt, hens supplemented with $\mathrm{SH}$ had higher oxidative activity. These data agree with Ibuki et al (27), who found that HD11 chicken macrophages treated in vitro with mannobiose increased the production of hydrogen peroxide in comparison to untreated macrophages. Similarly, Babu et al (28) challenged HD11 macrophages with Salmonella enteritidis and found that superoxide anion production was higher than in murine macrophages.

Although forced molting is practiced in production systems to increase the productive life of chickens and improve production and egg quality parameters, there is evidence that in the postmolt stage the relationship between pathogens and host is altered. Therefore, eggs produced in the early post-molt period present a higher risk of contamination for humans since the percentage of contaminated eggs is increased (29). Results
Los resultados evidenciados en este trabajo sobre la aglutinación bacteriana, permiten inferir que la suplementación con $\mathrm{SH}$ al 0.1 y $0.2 \%$ mejoran el efecto de la aglutinación bacteriana en el suero de gallinas ponedoras $(p<0.05)$; Aunque no se encontraron datos publicados en esta especie para realizar comparaciones, estos resultados tienen relación con los presentados por Behera et al (18) quienes realizaron una inmunización parenteral con ácido glicólico en Rohita labeo reportando que el grupo tratado mostró una diferencia significativamente mayor en la prueba de aglutinación bacteriana el primer día de inmunización sin obtener diferencia significativa a los 21 y 42, datos que difieren de los resultados presentados en este trabajo puesto que la suplementación con SH mejoró significativamente la aglutinación bacteriana en todos los muestreos (día 8,30 y 60 ).

La actividad de la Lisozima demostró mejorar significativamente el día 60 con una suplementación de $0.1 \%$ de SH. De acuerdo con Li et al (26), en la naturaleza el huevo es el recurso más rico en Lisozima. De ahí que es pertinente estudiar si el aumento en el grosor de la albúmina del huevo tiene relación con un aumento en la proporción de Lisozima y a su vez con la inmunidad transferida en el huevo a nivel de reproductoras.

El suero sanguíneo de las gallinas suplementadas con SH presentó una mayor aglutinación bacteriana durante todo el tiempo del experimento incluso superando el grupo control positivo, sin embargo de este tema no se encuentran publicaciones sobre resultados previos.

Los resultados de la prueba de explosión respiratoria demostraron que al día 30 de la posmuda las gallinas suplementadas con SH presentaban una mayor actividad oxidativa. Estos datos concuerdan con Ibuki et al (27), quienes encontraron que los macrófagos de pollo HD11 tratados in vitro con manobiosa incrementan la producción de peróxido de hidrógeno comparado con macrófagos no tratados. Igualmente, Babu et al (28) desafiaron macrófagos HD11 con Salmonella enteritidis y encontraron que la producción de anión superóxido era mayor que en los macrófagos de origen murino.

A pesar que la muda forzada se realiza en la práctica de sistemas de producción para prolongar la vida productiva de las gallinas para mejorar los parámetros productivos y de calidad de los huevos, se ha evidenciado que en la etapa posmuda se altera la relación entre los patógenos y el hospedador, por consiguiente los huevos producidos en el período temprano de la posmuda representan un mayor riesgo de contaminación para el consumo humano aumentándose el porcentaje 
reported in this study show that supplementing laying hens in the post-molt phase generated significant increases in IF, lysozyme activity and serum bactericidal activity during the early postmolt stage (Day 8 and 30), whereas the same supplementation in the mid post-molt stage (day $60)$ decreases IF markedly and does not present stimulatory effects on respiratory burst activity or lysozyme, however bacterial agglutination is stimulated at all measured times.

In conclusion, information in this study suggests that supplementation of laying hens during the postmolt phase with $\mathrm{SH}$ from the biotransformation of cachaza, leaf and sugar cane vinasse, can act as stimulants on the parameters of innate immunity evaluated in laying hens particularly in the early stage of this phase, considering that it had higher IF (Day 8 and 30), bacterial agglutination increased during the whole experiment (day 8 , 30 and 60), even surpassing the control group, increasing bactericidal activity of the serum on day 8 and 30 , and lysozyme activity was significantly better on day 60 of supplementation.

\section{Acknowledgments}

The present study was carried out thanks to the financial and logistical contribution at the University of Tolima and the Universidad Cooperativa de Colombia. Thanks to Felipe Velasquez Rodriguez and Adriana Claudia Cely of the Universidad Cooperativa de Colombia and to the Veterinary Diagnostic Laboratory at the Universidad de Tolima. de huevos contaminados (29). Los resultados reportados en esta investigación demuestran que suplementando las gallinas ponedoras en la fase posmuda se generan incrementos significativos en el IF, actividad de la lisozima y actividad bactericida del suero durante la etapa temprana de la posmuda (día 8 y 30), mientras que con la misma suplementación en la etapa media de la posmuda (día 60) decrece marcadamente el IF, y no presenta efecto estimulante sobre la explosión respiratoria ni la actividad de la lisozima, no obstante la aglutinación bacteriana es estimulada en todos los tiempos medidos.

En conclusión, la información obtenida en la presente investigación indica que la suplementación de gallinas ponedoras durante la fase de posmuda con SH provenientes de la biotransformación de la cachaza, hoja y vinaza de caña de azúcar pueden actuar como estimulantes de los parámetros de la inmunidad innata evaluados en gallinas ponedoras particularmente en la etapa temprana de dicha fase, teniendo en cuenta que presentó mayor IF (día 8 y 30 ), se incrementó la aglutinación bacteriana durante todo el tiempo del experimento (día 8, 30 y 60 ) incluso superando el grupo control, aumentó la actividad bactericida del suero el día 8 y 30 , y la actividad de la lisozima fue significativamente mejor el día 60 de suplementación.

\section{Agradecimientos}

El presente estudio se realizó gracias a la contribución financiera y logística de la Universidad del Tolima, y la Universidad Cooperativa de Colombia. Agradecimientos a Felipe Velásquez, Claudia Rodríguez y Adriana Cely de la Universidad Cooperativa de Colombia así como al Laboratorio de Diagnostico Veterinario de la Universidad del Tolima.

\section{REFERENCES}

1. Van den A, London N, Driessen C, Stobberingh E. Antibiotic resistance of faecal Escherichia coli in poultry, poultry farmers and slaughterers. J Antimicrob Chemoter 2001; 47(6):763-771.

2. Pomorska-Mol L, Pejsak Z. Effects of antibiotics on acquired immunity in vivo current state of knowledge. Pol J Vet Sci 2012; 15(3):583-588.
3. Akhtar M, Tariq A, Awais M, Iqbal Z, Muhammad F, Shahid M, HiszczynskaSawicka E. Studies on wheat bran arabinoxylan for its immunoestimulatory and protective effects avian coccidiosis. Carbohydr Polym 2012; 90(1):333-339.

4. Foster N, Berndt A, Lalmanach A, Methner $U$, Pascquali $P$, Rychlich I, et al Emergency and therapeutic vaccination - is stimulating innate immunity an option?. Res Vet Sci 2012; 93(1):7-12. 
5. Wondmeneh E, Getachew T., Dessie T. Effect of Effective microorganisms $\left(\mathrm{EM}^{\circledR}\right)$ on the growth parameters of fayoumi and Horro chicken. Int J Poult Sci 2011; 10(3):185-188.

6. VIcová Z. Chemical and physical transformations of humic acids. [Tesis Doctoral]. BRNO University id technology, Faculty of chemistry, Institute of physical and applied chemistry: Brno, República Checa; 2009.

7. Ergin O, Ocak N, Turan A, Erener G, Altop A, Cankaya S. Performance, carcass, gastrointestinal tract and meat quality traits and selected blood parameters of broilers fed diets supplemented with humic substances. J Sci Food Agric 2011; 92(1):59-65.

8. Eren M, Gezen S, Deniz G, Orhan F. Effects of liquid humate supplemented to drinking water on the performance and eggshell quality of hens in different laying periods. Revue Med Vet 2008; 159(2):91-95.

9. Sanmiguel R, Rondon I. Suplementación con sustancias húmicas en gallinas ponedoras durante la fase posmuda. Rev CES Med Zootec. 2014; 9(2): 169-178.

10. El-Deek A \& Al-harthi M. Post molt performance parameters of broiler breeder hens associated with molt induced by feed restriction, high dietary zinc and fasting. Int J Poult Sci 2004; 3(7):456-462.

11. Hassanien H. Effect of force molting programs on egg production and quality of laying hens. Asian J Poult Sci 2011; 5(1):1320.

12. Tega $E$, Ibrahim T. Effect of induced molting on fertility and hatchability chickens. Continental J Anim Vet Res 2010; 2(1):31-34.

13. Moreno-Rueda G. Experimental test of a trade of between moult and immune response in house sparrows Passer domesticus. J Evol Biol 2010; 23(10):2229-2237.

14. Akram M, Zia-ur-rahman C, Kim S. Effect on the induced molting on the relative weights and hormone levels of thyroid, ovary and adrenal glands in spent laying hens. Korean J Poult Sci 2002; 29(4):243-247.
15. Millet S, Bennett J, Lee K, Hau M, Klasing K. Quantifying and comparing constitutive across avian species. Dev Comp Immunol 2007; 31(2):188-201.

16. Wells L, Lowry V, Deloach J, Kogut M. Age dependent phagocytosis and bactericidal activities of the chicken heterophil. Dev Comp Immunol 1998; 22(1):103-109.

17. Mohanty B, Sahoo P. Immune response and expression profiles of some imune related genes in Indian major carp, Labeo rohita to Edwardsiella tarda infection. Fish Shellfish Immunol 2010; 28(4):613-621.

18. Behera $T$, Nanda $T$, Mohanty $C$, Mohapatra D, Swain P, Das B, et al. Parenteral immunization of fish, Labeo rohita whit poly D L- lactide Co- glycolic acid (PLGA) encapsulated antigen microparticles promotes innate and adaptive immune responses. Fish Shellfish Immunol 2010; 28(2):320-325.

19. Low K, Sin P. In vivo and in vitro effects of mercuric chloride and sodium selenite on some non-specific immune responses of blue gourami, Thricogaster trichopterus (Pallus). Fish Shellfish Immunol 1996; 6(5):351-362.

20. Harmon B. Avian heterophils in inflammation and disease resistance. Poult Sci 1998; 77: 972-977.

21. Lim TS, Na K, Choi EM, Chung JY, Hwang JK, Immunomodulating activities of polysaccharides isolated from Panax ginseng. J Med Food 2004; 7(1):1-6.

22. Engstad C, Engstad R, Olsen J, Osterud B. The effect of soluble-1,3-glucan and lipopolysaccharide on cytokine production and coagulation activation in whole blood. Int J Immunopharmacol 2002; 2(11):1585-1597.

23. Huammitri P, Redmond S, Kimura K, Andreasen C, Lamont S, Palic D. Heterophil functional responses to dietary immunomodulators vary in genetically distinct chicken lines. Vet immunol immunopathol 2011; 142(3):219-227. 
24. Jiao I, Wank D, Zhang X, Li B, Zhao $H$, Liu S. Characterization and immunostimulating effects on murine peritoneal of oligosaccharide isolated from Panax ginseng C.A Meyer. J Ethnopharmacol $2012 ; 144(3): 490-496$.

25. Swaggerty C, Pevzner I, Ferro P, Crippen $T$, Kogut M. Association between in vitro heterophil function and the feathering gene in commercial broiler chickens. Avian Pathol 2003; 32(5):433-438.

26. Li B, Y Huang, Paskewitz S. Hen egg white lysozyme as an inhibitor of mushroom tyrosinase. FEBS Letter 2006; 580(7):18771882.
27. Ibuki M, Kovacs-Nolan J, Fukui K, Kanatani $\mathrm{H}$, Mine Y. B 1-4 mannobiose enhances Salmonella Killing activity and activate innate immune responses in chicken macrophages. Vet Immunol Immunopathol 2011; 139(2-4):289-295.

28. Babu U, Gaines D, Lillehoj H, Rayburn R. Differential reactive oxygen and nitrogen production and clearance of Salmonella serovars by chicken and mouse macrophages. Dev comp immunol 2006; 30(10); 942-953.

29. Woodward C, Kwon Y, Kubena N, Byrd J, Moore R, Nisbet D, Ricke S. Reduction of Salmonella enterica serovar enteritidis colonization and invasion by an alfalfa diet during molt in leghorn hens. Poult Sci 2005; 84(2):185-193. 